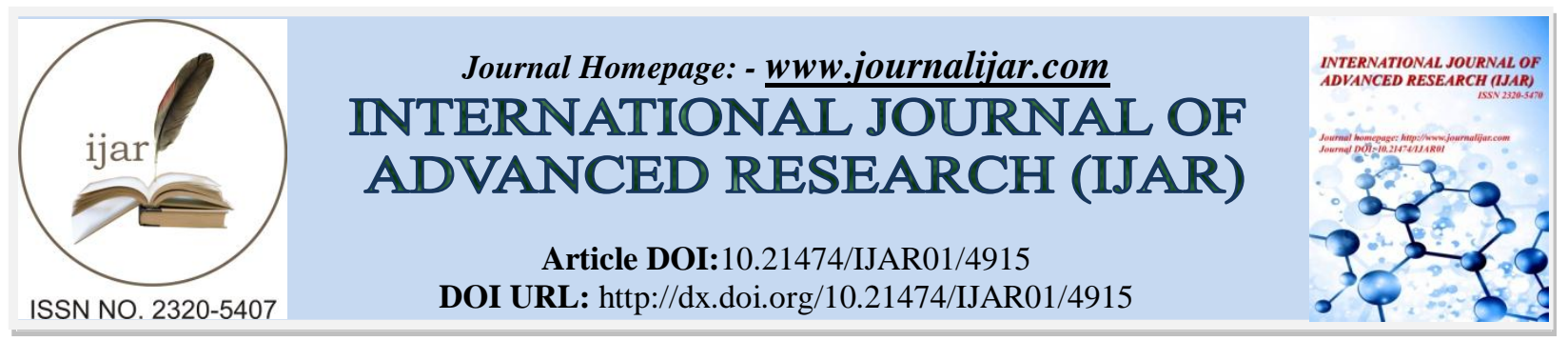

RESEARCH ARTICLE

\title{
STUDENTS' PERCEPTIONS OF INSTRUCTIONAL TECHNIQUES USED BY TUTORS IN UNIVERSITY OF ZAMBIA EXTENSION EDUCATION PROGRAMME IN LUSAKA DISTRICT.
}

\author{
Davies Phiri ${ }^{1}$ and Wanga W. Chakanika ${ }^{2}$. \\ 1. Traditional Affairs Officer, Ministry of Chiefs and Traditional Affairs, Kazungula District. \\ 2. Senior Lecturer, University of Zambia, Zambia.
}

\section{Manuscript Info}

Manuscript History

Received: 22 May 2017

Final Accepted: 24 June 2017

Published: July 2017

\section{Abstract}

This study was a product of a Mixed methods Design. The universe population comprised all of the following: students that were enrolled in the UNZA extension education credit course in all the extension education centres within Lusaka District in the 2014/2015 academic year; the extension education centres within Lusaka District; and the graduates from the aforementioned courses and centres from the year 2013 to 2014 . The study had a total sample of 130 in which 115 were students who were selected using convenient sampling procedure and 15 were graduates who were traced through snow ball sampling procedure. 2 out of 11 extension education centres within Lusaka District were purposively selected and all respondents were from these same centres. A semi-structured questionnaire and an interview guide were used to collect data from 115 sand 15 graduates respectively.

The findings of this study elucidated that despite tutors in the UNZA extension education programme using a repertoire of different pedagogical strategies from both the teacher-centred and the studentcentred approaches to teaching, instructor-centred (i.e. lecture and dictation) teaching techniques were the most dominant. It was also established that both learner-centred and teacher-centred teaching techniques were preferred by some students but most students preferred active teaching techniques more than the passive ones.

This study therefore, recommended that the University of Zambia (UNZA), through the Department of Adult Education and Extension Studies (DAEES) should start providing refresher courses to tutors in extension education on adult education teaching techniques.

Copy Right, IJAR, 2017,. All rights reserved.

\section{Introduction:-}

This article is based on the study entitled: Students' Perceptions of Instructional Techniques used by Tutors in University Of Zambia Extension Education Programme in Lusaka District. Since the year 2009 when the University of Zambia (UNZA) infused credit courses in its Extension Education Programme, tutors were teaching without any empirical evidence on how their students perceived the teaching techniques that they were using. However, literature suggests that for effective teaching to take place, educators should be aware of their students' perceptions regarding the teaching techniques they employ. For instance, Etuk, Afangideh and Uya (2013:197) argued that the knowledge 
of the way the students think and perceive can aid the teacher to reflect upon and adjust his teaching strategies to enhance students' understanding and achievement.

Thus, the problem for this emerged from the fact that nothing was known with regards to the perceptions that students in credit courses had on the instructional techniques used by their Tutors since 2009. Its purpose therefore, was to establish such perceptions. The objectives of this study were to: i) explore students' views on the types of teaching techniques that dominate their learning environment; and ii) ascertain students preferred teaching techniques.

It was presupposed that through this study, the University of Zambia in general and the Department of Adult Education and Extension Studies in particular could be made aware of the perceptions that students had on teaching techniques used by their tutors in credit courses under the extension studies section. Consequently, the findings of this study may call for amendments where possible. Additionally, the results of this study may act as reference material to not only lecturers and students in adult education at the University of Zambia but also to other students and administrators of adult education programmes in the field of social sciences. Of equal significance is to mention that the findings of this study have added on to the already existing knowledge on this subject.

This study bordered on University of Zambia extension education programme in Lusaka District. It targeted students and graduates from these same centres. Lusaka District was selected because it had the largest numbers of students in extension studies and had more active extension centres than any other District throughout the country.

\section{Theoretical framework and review of literature:-}

Theoretical Framework:-

Specifically, this study was guided by the Freirean theory of education. This theory was chosen due to the fact that it provides characteristics of both approaches to teaching that is, student-centred teaching and teacher-centred teaching approaches. Although Freire's theory seems to support the students-centred or problem posing approach to teaching, it also gives characteristics of teacher-centred teaching which were used to analyse what is obtaining in University of Zambia Extension Education. Put it another way, this study needed a two-sided theory that explained characteristics of both approaches to teaching.

Paulo Freire introduced a radical distinction that has since become a feature of progressive educational thought: the difference between what he called "banking" and "problem-posing" education. According to Freire (1970:71) Banking education resists dialogue; problem-posing education regards dialogue as indispensable to the act of cognition which unveils reality. Banking education treats students as objects of assistance; problem-posing education makes them critical thinkers. Problem-posing education bases itself on creativity and stimulates true reflection and action upon reality, thereby responding to the vocation of men as beings who are authentic only when engaged in inquiry and creative transformation.

The forgoing connotation indicates that Banking Education is synonymous to non-participatory or teacher-centred approach to teaching. On the other hand, Problem-posing teaching is also known as participatory or leaner-centred teaching approach.

\section{Literature on frequently used instructional techniques:-}

According to Adib-Hajbaghery and Aghajani (2011), there is enough evidence from research studies indicating that most of the university teachers are not familiar with modern teaching methods; and that traditional lectures are still the most popular instructional method in the universities. This claim is consistent with Brown's (2003) argument that most of the university teachers have been taught in learning environments that were instructor-centered, therefore, they teach in that way too.

Sakala (2012) conducted a study on factors that contributed to excess use of the lecture method of teaching among high school teachers in selected high schools of Kitwe and Kalulushi districts in the Copperbelt Province of Zambia. The findings from the study showed that teachers had been exposed to a variety of teaching methods and techniques during their initial teacher training. It was further reported in this same study that down the line as they practiced their career, teachers resorted to using the lecture technique more than any other teaching technique.

A similar study by Namangolwa (2013), revealed that when pupils were asked to explain how often learnercentered methods were used during the teaching and learning of history, most of them indicated that their teachers 
rarely used quizzes, debates, discovery learning, drama, role play and projects. This same study also reported that majority teachers indicated that they did not frequently use quizzes, debates, discovery learning, drama and projects; and that all the teachers said that they had never used field trips in their teaching. Namangolwa (2013) further reports that when pupils were asked to state whether they found learner-centered methods easier and interesting to learn history with and the benefits of using such methods, many pupils were of the view that learner-centered methods were interesting because they helped them share ideas. Despite that, teachers did not use active teaching strategies, an indication of the continued dominance of traditional passive teaching techniques.

However, this study was not a replica of the forgoing two studies. For example, the general aim of a study by Sakala (2012) was to investigate factors contributing to the excess use of the lecture method of teaching. However, this study aimed at exploring students' perceptions of teaching techniques used by tutors. Unlike Sakala's study, this study did not presuppose that a lecture technique was extensively used by tutors in University of Zambia (UNZA) Extension Education programmes. However, the findings of this study directed the researcher on which techniques were used frequently by tutors in extension programmes. Similarly, a study by Namangolwa (2013), did not correspond with what this study intended to investigate. For instance, Namangolwa's study was aimed at exploring the perceptions of teachers and pupils regarding learner-centered (otherwise active teaching strategies) techniques. On the contrary, this study investigated on the students perceptions of teaching techniques that were used by their tutors, be it active or passive teaching techniques.

Of equal significance is to mention that the two studies by Sakala (2012) and Namangolwa (2013) were conducted in selected high schools and not in postsecondary or adult education institutions. Therefore, their findings could not have been generalised to postsecondary institutions of learning.

In 2004, Liu, Qiao and Liu (2004) conducted a study entitled: A Paradigm Shift of Learner-Centered Teaching Style: Reality or Illusion? The results indicated that the dominant teaching style of University Graduate Associate in Teaching (GATs) was teacher-centered. In supporting their argument, Liu, Qiao and Liu (2005) quoted Spoon and Schell (1998) who also reported a moderate preference for a teacher-centered approach by both teachers and learners in adult education; and Conti (2004) who concluded that teacher-centered style is "currently the dominant approach throughout all levels of education in North America" (Liu, Qiao \& Liu, 2004). Their conclusion was that though the learner-centered approach is praised in research and practice to address individual learners' needs, instructors still use traditional, teacher-centered styles in University settings. This is also consistent with Lammers and Murphy (2002) who argued that the lecture is a teaching technique that has a long history in academe. However, these studies were not conducted in any of the Zambian academe. Therefore, the findings of these studies may not reflect what this current study discovered and can also not be generalised to the Zambian context.

Cuseo (1996) quoted in Cooper, Robinson, and Ball (nd:1), is of the view that despite calls for the radical transformation of teaching and learning in higher education to a more constructivist, collaborative learning approach, the lecture remains the dominant mode of instruction for most teachers. However, Beausaerta, Segersa, and Wiltink (2013), report contrasting findings. They indicated that students in Dutch-language courses perceived their teachers as more student-centered, and were hence more likely to adopt a deep approach to learning than students in mathematics courses.

\section{Literature on Students preferred teaching techniques:-}

It is believed that students learn both passively and actively. "Passive learning takes place when students take on the role of "receptacles of knowledge"; that is, they do not directly participate in the learning process.... Active learning is more likely to take place when students are doing something besides listening" (Ryan and Martens 1989:20).

The findings of study by Maphosa, Zikhali, Chauraya and Madznire (2013) on students' perceptions of the utility of pedagogical approaches used by lecturers in selected faculties at a Zimbabwean University interested our study. The results of this study with regards to preferred teaching techniques by students were ranked in order of popularity as follows; the lecture method with discussion, followed with practicals/attachments, the traditional lecture method, field work, class discussion, small group discussions, question and answer and panel of experts. The least popular were guest speakers, brainstorming, laboratory work and tutorials. Based on the aforesaid results, Maphosa, Zikhali, Chauraya and Madznire, (2013:119) made the following claim:

It looks the results are confirming that students prefer deep approaches to learning and prefer methods which are activities based. Maybe the traditional lecture method is popular because students are just used to it since it is the main mode of transmission at tertiary level. 
In trying to justify their claim, Maphosa, Zikhali, Chauraya and Madznire (2013) further noted that the finding in the study that students perceived lecture with discussion as an effective pedagogical approach confirmed the importance of student involvement in learning as opposed to wholly lecturer dominated teaching sessions. These results were in tandem with Carpenter (2006:18) who discovered that students preferred lectures combined with some discussions. The researcher noted that the finding suggests that most students enjoy a blend that includes at least some component of active learning/participation in combination with traditional lecture, and confirms the importance of including some level of discussion during the class, but also providing structure through an organized lecture.

The forgoing findings did not much with the findings of the study by Shaari, Yusoff, Ghazari, Osman and Dzahir (2014). When researching on the relationship between lecturers' teaching style and students' academic engagement, these researchers discovered that students preferred use of interactive teaching techniques to traditional lecture methods. They reported that In terms of cooperation, the majority of students give full cooperation to other students when they are doing group work which $89.3 \%$ agreed with the item. The majority of respondents also enjoy doing extra work which $87.8 \%$ agreed with the item. A total of $79.1 \%$ of the respondents prefer to ask the lecturer if they do not understand what is taught by the lecturer (p.15).

A study by Sajjad (n.d), provides further evidence that students continue to prefer traditional lecture technique to participatory teaching strategies. The researchers sampled two hundred and twenty (220) undergraduate students studying in 11 departments of Faculty of Arts of University of Karachi, and these were asked to state their perceptions of best and effective teaching methods and the reason for that. This researcher sampled the following teaching techniques and used them to obtain students perception towards them: lecture; group discussion; individual presentation; assignments; seminars; workshop; conferences; brainstorming; role play; and case study techniques. Sajjad (n.d:4) summarized the results of this study as follows Most of the students rated lecture method as the best teaching method. Reasons included; teacher provides all knowledge related to topic, it is time saving method; students listen to lecture attentively and take notes etc. The group discussion was rated as the second best method of teaching because of; more participation of students, the learning is more effective, the students don't have to rely on rote learning, and this method develops creativity among students etc. Students' perception and ratings about the interesting and effective teaching methods is a way to suggest improvements in teaching learning process Based on the results of the three (3) foregoing studies, it is clear that students' preferences of teaching techniques may vary from one country to another. These three (3) studies reported different findings and this proved the fact that foreign studies may not reflected the situation as it obtained in Zambia. It was therefore, important to conduct this study and address the second objective since it was clear that there was a dearth of empirical evidence on the preferred teaching techniques by students in University of Zambia (UNZA) Extension Education programmes.

Another study conducted by Kumar and Lightner (2007) reported interesting results concerning perceptions of Teaching techniques. This two-part study investigated perceptions of interactive classroom teaching techniques for learning. In the first part of the study 62 college faculty members and 45 corporate trainers were surveyed on their teaching and training methods. The survey had two main objectives: to determine rates of classroom techniques used, and to determine influences on teaching styles. Trainers used a greater variety of teaching techniques in their presentations, such as visuals interactive exercises including games, and spent less time on lecturing than their college counterparts. In the second part of the study, five faculty members were mentored to change traditional lectures interactive games. A review of their perceptions of success and difficulty in using such activities in the college classroom, their students' perceptions of the exercise, and student performance identified both benefits and costs. Kumar and Lightner (2007:58) further reported that when students were asked the amount of time they would prefer to have in the traditional lecture format, their average response was $51 \%$. Interestingly, their responses were closer to the amount of time trainers actually lecture $(56 \%)$ than that of professors, who spend $67 \%$ of class time lecturing. One of our faculty interviewees expressed hesitation at incorporating active learning strategies and games, worrying that students are expecting to be taught or told and should "get their money's worth." However, in the survey, the students expressed a preference for less time spent lecturing than instructors report lecturing, so these instructors' concerns may have been unwarranted.

The aforesaid quotation indicates that students responded positively to the new active learning exercises that replaced traditional lecture. As Kumar and Lightner (2007:58) concluded; students indicated that due to active learning techniques, they "learnt a lot, it was not a waste of their time, that the activity was enjoyable, accomplished its goal, and they wished more faculty members used such activities." 
The foregoing study differed with this current study in two major ways. First, the study by Kumar and Lightner (2007) was a two-part study. The first party of the study compared teaching techniques used by faculty lecturers to those used by cooperate trainers; and it was discovered that cooperate trainers used participatory teaching techniques more that faculty lecturers. The second party aimed at establishing students' perceptions towards new participatory teaching techniques that certain faculty members used after being trained by cooperate trainers. However, the current study was not a two-part study. The aim of this study was to investigate the perceptions of students with regards to teaching techniques that their tutors used in the UNZA extension programmes. This study did not expose tutors to any training in instructional techniques and later explored students' perceptions towards those techniques. This was due to the fact that such an approach had the ability to influence students' perceptions of instructional techniques used by their tutors. In other words, this study was not a quasi-experimental design aimed at testing the effectiveness of one category of teaching techniques. Instead, the current study was a product of a Triangulation/Mixed Design approach that aimed at determining students' perception of teaching techniques used by tutors in the UNZA Extension Education programmes.

Ali (2011) reports on students' performance after two groups of students were each exposed to different teaching methods; cooperative learning and traditional lecture formats. His findings were that the responses from students exposed in a cooperative classroom included preferences for the cooperative session because it catered for interaction, participation, and discussion; but that some students found the noisiness created by their interactions with each other disturbing and this affected their learning. Ali (2011) further reports that responses from students exposed to a lecture format included their preference for the lecture because this method allowed the teacher to lead in a structured way as compared to the group work were discussion among students lead to unnecessary chatter.

Again, the approach used by Ali (2011) may have influenced students' perceptions. The researcher had two categories of respondents with some exposed to interactive teaching techniques while others confined to passive teaching techniques. The results coming from studies of that nature are likely to be biased as they may reflect students' perception of one category of teaching techniques to which they were exposed. However, the current study intended to investigate students' perceptions of the teaching techniques that tutors in UNZA extension programme used that may have fallen in either of the two broad categories of teaching techniques namely teacher-centred and student-centred teaching approaches.

\section{Methodology:-}

This study was a product of both qualitative and quantitative methods. This allowed collection of both qualitative and quantitative data concurrently, and equal priority was given to both data sets throughout the research process.

The universe population included the following: all students that were enrolled in credit-based courses of UNZA extension programme within Lusaka District in the 2014/2015 academic year; and all graduates from the aforementioned courses and centres from the year 2013 to 2014.

A total sample of 130 had two segmented of respondents. The first set included 115 were students and these were sampled using convenient sampling procedure. This is due to the fact that data collection was done when student were on their academic vacation. The second segments comprised 15 graduates and these were traced through snow sampling procedure as they could not be easily accessed. Purposive sampling was used to select two (Ridgeway and UNZA) centres out of 11 cetntres within Lusaka District as these were the most active centres within Lusaka District.

The researcher collected data by physically distributing self-administered semi-structured questionnaires to students and conducting semi-structured interviews with graduates with the help of an interview guide. Issues of anonymity and confidentiality were also observed throughout the research process for ethical consideration purposes.

Qualitative data were analysed using excel and SPSS to generate frequency table and graphs. On the other hand, qualitative data were subjected to a constant comparative analysis to identify emerging themes and these themes were then supported by respondents' verbatim.

\section{Findings:- \\ Research question 1: What were the views of students on the types of teaching techniques that dominate their learning environment?}

Question one sought to establish what the views of students were on the types of teaching techniques that dominate their learning environment. All categories of respondents (graduates and students) confirmed utilization of both participatory and non-participatory teaching techniques by tutors in UNZA Extension Education programme. Figure 1 below shows respondents' views on the teaching techniques used by their tutors. Students were asked to indicate 
either Yes or No to each one of seven techniques given depending on whether or not their tutors used them. The scores were as displayed in Figure 1 below:

Figure 1:- Perceived Dominant Teaching Techniques.

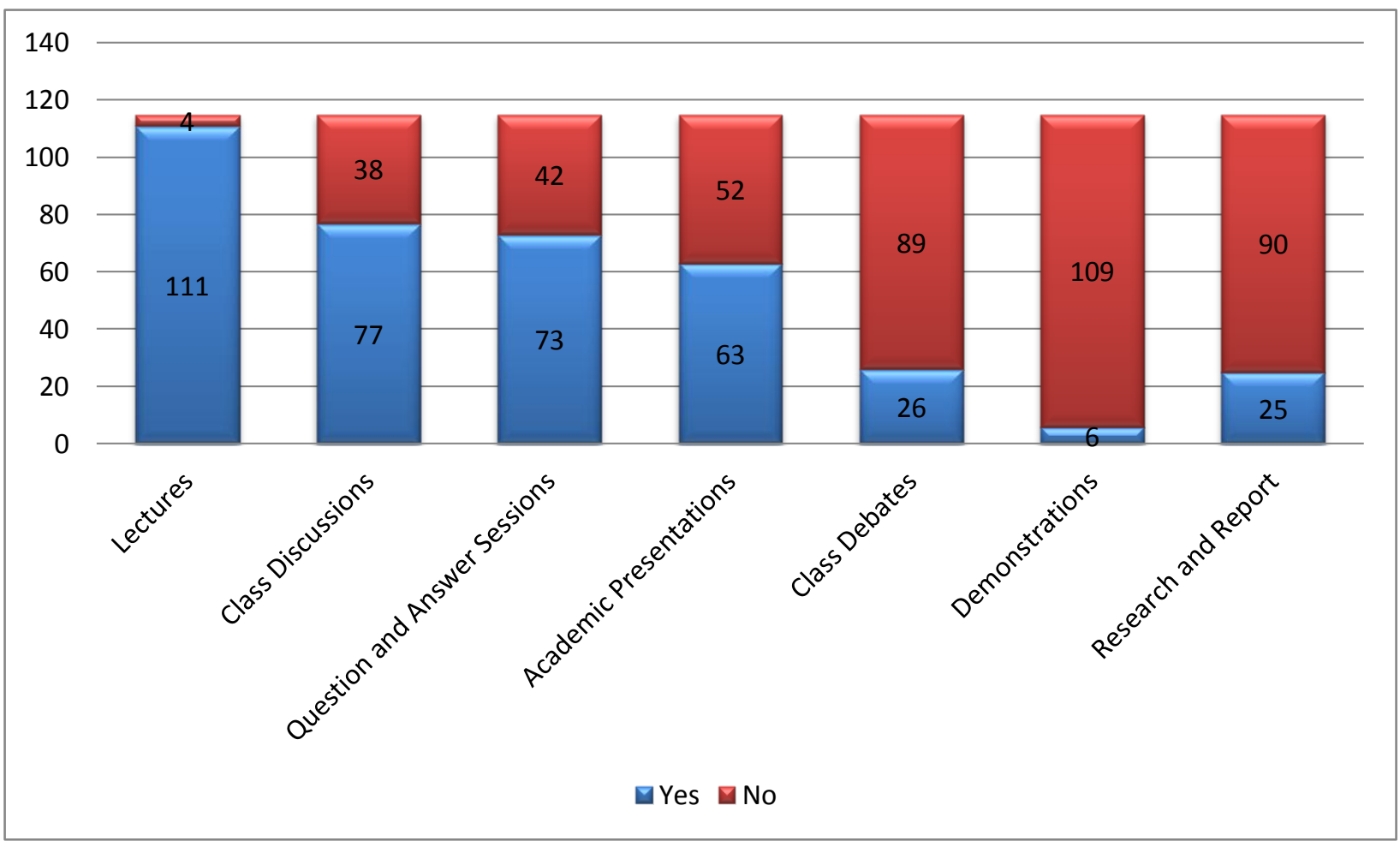

However, it was established that majority students $(99=86.1 \%$ of 115 respondents $)$ were of the view that a lecture technique was the most dominant teaching techniques used by their tutors. Table 1 below gives a summary of the dominant teaching techniques in extension education as indicated by the respondents.

Table 1:- Distribution of Respondents by their perceived dominant teaching techniques.

\begin{tabular}{|l|l|l|}
\hline & Frequency & Percent \\
\hline Lecture & 99 & 86.1 \\
\hline Group Discussions & 8 & 7.0 \\
\hline Question and Answer Session & 3 & 2.6 \\
\hline Academic Presentations & 2 & 1.7 \\
\hline Class Debates & 1 & .9 \\
\hline Research and Report & 2 & 1.7 \\
\hline Total & 115 & 100.0 \\
\hline
\end{tabular}

Qualitative findings also revealed use of both students-centred and teacher-centred teaching techniques by tutors in extension education programme but confirmed the fact that students perceived their learning environment to have been dominated by instructor-centred teaching techniques as opposed to the learner-centred ones. Themes that emerged included: extensive use of lecturing and dictation; use of question and answer sessions, but mostly at the end of lectures; extensive use of teaching techniques that promoted less Students-Tutor and Student-Student interaction; and abuse of handouts and modules as teaching techniques instead of teaching aids. Conclusively therefore, it was established that the general view by students was that their learning environment was dominated by instructor-centred teaching techniques.

\section{Research question 2: What were the students' preferred teaching techniques?}

Research question number two (2) sought to answer what students' preferred teaching techniques were in UNZA extension education programme. All the one hundred and fifteen (115) students indicated their preferences to each on the teaching techniques in figure 1 below by selecting either Yes or No. As indicated in figure 2 below, it was 
established that 76 (66\%) respondents and $65(57 \%)$ respondents did not prefer lecture format and demonstration respectively. The same figure further shows the teaching techniques that were preferred in the following order: group discussions by 107 (93\%) respondents; academic presentations by 91 (79\%) respondents; class debates by 88 (77\%) respondents; research and report by 86 (75\%); and question and answer sessions by 85 (74\%) respondents.

Figure 2:- Preferred Teaching Techniques

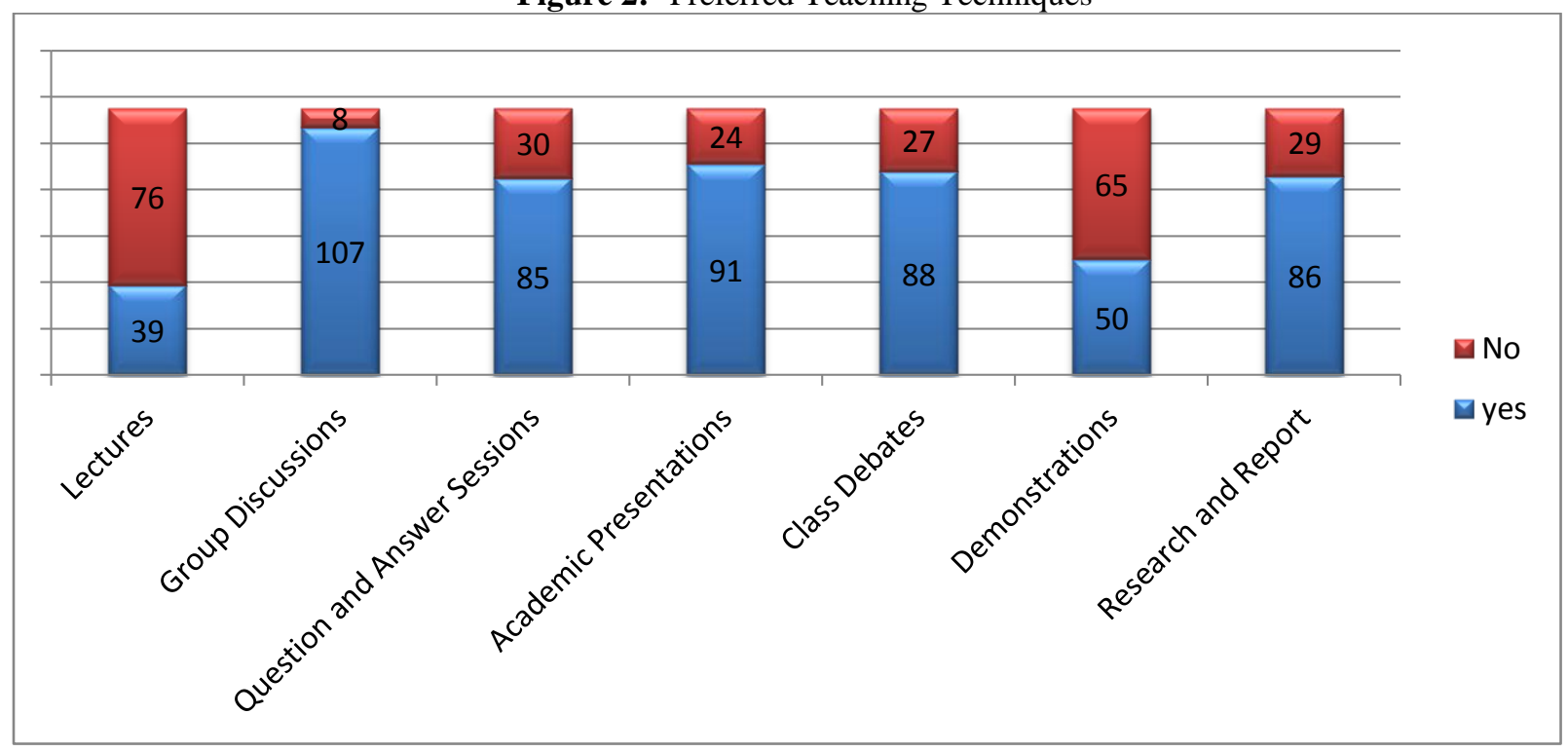

Quantitative findings from respondents were in tandem with qualitative findings. It was established that students' preferred teaching techniques included those that promoted freedom of interaction and participation in the teaching and learning process. They also preferred those teaching techniques that incorporated technological teaching aids, as well as those that improved their research skills.

\section{Discussion:- \\ Objective 1:-Explore students' views on the types of teaching techniques that dominated their learning environment. \\ Objective one (1) sought to establish students' views on the teaching techniques that dominated their learning environment. Although it was generally agreed by respondents that both approaches to teaching were used by tutors, the findings further demonstrate that instructor-centred teaching techniques were the most dominant teaching techniques in the UNZA extension programme. For instance it was established that majority students $(99$ or $86.1 \%$ of 115 respondents) were of the view that a lecture technique was the most dominant teaching techniques used by their tutors. Similarly, qualitative findings confirmed the fact that students perceived their learning environment to have been dominated by instructor-centred teaching techniques as opposed to the learner-centred ones. This supports Cuseo's (1996) cited in Cooper, Robinson, and Ball (nd:1) conclusion that despite calls for the radical transformation of teaching and learning in higher education to a more constructivist, collaborative learning approach, the lecture remains the dominant mode of instruction for most teachers.}

Furthermore, these findings seem to substantiate Freires' (1970) assumption that a formal education system (a banking education system) tends to be an instructor-centred dominated system. These findings are from students and graduates of credit courses that form the formal section of the University of Zambia extension education programme as they are provided following senate-approved and prescribed curricular, calendars and regulations. The findings revealed that the teaching environment in these courses was dominated by instructor-centred pedagogies, and as such limited students' active participation in the learning process. These revelations authenticate Friere's (1970) analysis of the limitations of the prescriptive style of teaching and education system. Freire firmly believed that schools use the "banking method" to domesticate students.

Objective 2:- Establish students preferred teaching techniques:-

The second objective sought to establish the teaching techniques preferred by students. It was established that both learner-centred and teacher-centred teaching techniques were preferred. However, consistent with previous claims 
and studies (Freire, 1970; Carpenter, 2006), the findings for this current study also support the assertion that adult learners and students in post-secondary institutions of learning tend to prefer active teaching techniques more than the passive ones. This study was conducted in the UNZA extension education programme whose clientele are those that qualify to be adult learners. This seems to be reason why student-centred techniques were preferred more than teacher-centred techniques.

The study also unearthed that teaching techniques that integrated technological teaching aids (including lectures and direct demonstrations) were preferred by some students but were rarely used by their tutors. To others, this finding may seem contradictory to Freire's assumption that instructor-centred teaching techniques are inappropriate to adult learners. Such interpretations may be misleading and cannot hold. In fact, students' revelation of their preference to lecture techniques that are accompanied by technological teaching aids is an indication that traditional lecture formats need modifications if they are to be liked. Carpenter (2006:18) made a similar conclusion after discovering that students preferred lectures combined with some discussions. The researcher noted that the finding suggests that most students enjoy a blend that includes at least some component of active learning/participation in combination with traditional lecture, and confirms the importance of including some level of discussion during the class, but also providing structure through an organized lecture.

Coincidently, Maphosa, Zikhali, Chauraya and Madznire (2013) also concluded that their findings that students perceived lecture with discussion as an effective pedagogical approach confirmed the importance of student involvement in learning as opposed to wholly lecturer dominated teaching sessions. This proves the fact that traditional lectures are perceived effective and are appreciated by many if they are modified. In this case, it is not a lecture technique per se, but an eclectic approach to teaching in which a lecture technique is only a component.

\section{Conclusion:-}

The first objective unearthed the fact that despite tutors using both student-centred and teacher centred approaches in teaching, students in the UNZA extension education programme in Lusaka District perceived their learning environment to be dominated by instructor-centred teaching techniques. The second objective revealed that while some students preferred student-centred teaching techniques, others were in favour of instructor-centred teaching techniques. However, student-centred teaching techniques emerged as the most preferred teaching techniques. Based on the these findings therefore, it can be construed that the most used teaching techniques by Tutors in UNZA Extension programme were not necessarily the most preferred by students. Thus, Freire's assumption that school systems tend to adopt the banking approach to teaching is as valid as it was the very day it was pronounced. His hypothesis that adult learners are fond of participatory teaching techniques was also proven to be true.

\section{Recommendations:-}

Based on the findings, discussions and conclusion, the study makes the following recommendations:-

1. the University of Zambia (UNZA) through the Department of Adult Education and Extension Studies (DAEES) should start providing refresher courses to tutors in extension education programmes on adult education teaching techniques. This would make them realise how unique adult learners are and that certain teaching techniques should only be employed where necessary;

2. alternatively, the Department of Adult Education and Extension Studies must deliberately include Adult education teaching methods and techniques as some of the requirements for graduates intending to be engaged as tutors;

3. the Department of Adult Education and Extension Studies must introduce Students' Evaluation of Teachers (SET) system as done in many international universities. This would enable students to air their views on the teaching techniques used by their tutors and these would be used to make amends where possible; and

4. the Resident Lecturer and Centre Coordinators must start monitoring the tutors' attendance on daily basis.

\section{Acknowledgements:-}

I would like to express my sincere gratitude and appreciation to my supervisor Wanga, W. Chakanika who patiently read every chapter in this Report, critiqued them and provided suggestions. His patience, kindness, fatherly heart and editorial expertise gave this study its present shape. Being under his supervision was indeed a blessing I shall forever cherish. 
Our heartfelt appreciations go to Dr. Gift Masaiti and Dr. Emmy Mbozi for advice and assistance that we received especially during the formative stages of this piece of work. The role they played in making this work a reality cannot go unnoticed and shall forever be remembered.

Ma we also record our gratitude to the management, tutors, students and graduates of the University of Zambia (UNZA) extension programme in Lusaka District for the cooperation that they rendered to us during the collection of data. Without these, this work would not have been accomplished.

\section{References:-}

1. Abdelmalak, M. and Trespalacios, J. (2013). "Using a learner-centered approach to develop educational technology course." International Journal of Teaching and Learning in Higher Education, 25(3):324-332.

2. Adib-Hajbaghery, M., and Aghajani, M. (2011). Traditional Lectures, Socratic Method and Student Lectures: Which one do the Students Prefer? Retrieved from http://www.webmedcentral.com/article_view/1746

3. Beausaerta, S.A.J., Segersa, M.S.R., and Wiltink, D.P.A. (2013). "The influence of teachers' teaching approaches on students' learning approaches: the student perspective.” Educational Research, 55(1): 1-15.

4. Ali, H. (2011). "A comparison of cooperative learning and traditional lecture methods in the project management department of a tertiary level institution in Trinidad and Tobago." Caribbean Teaching Scholar, 1(1): 49-64.

5. Brown, B.L. (2003). "Teaching Style vs. learning style." Eric clearinghouse on adult, career, and vocational education, 26(2003): 1-2.

6. Carpenter, J.M. (2006). "Effective teaching methods for large classes." Journal of Family \& Consumer Sciences Education, 24(2): 13-23.

7. Cooper, J., Robinson, P., and Ball, D. (nd). "The Interactive Lecture: Reconciling Group and Active Learning Strategies with Traditional Instructional Formats." The Online Journal of Teaching and Learning in the CSU. Retrieved from http://www.exchangesjournal.org

8. Conti, G. J. (2004). Identifying Your Teaching Style. Malabar, FL: Krieger Publishing Company.

9. Cummins, J. (2007). "Pedagogies for the poor? Realigning reading instruction for low-income students with scientifically based reading research." Educational Researcher, 36(9): 564-573.

10. Cuseo, J. (n.d.). The case for student evaluation of college courses. Policy Center on the First Year of College. Retrieved May 27, 2002, from http://www.brevard.edu/fyc/fya/CuseoLink.htm

11. Etuk, E.H., Afangideh, M.E., and Uya, A.O. (2013). “Students' Perception of Teachers' Characteristics and Their Attitude towards Mathematics in Oron Education Zone, Nigeria. "International Education Studies, 6(2): 197-204.

12. Friere, P. (1970). Pedagogy of the Oppressed. New York: Herder and Herder.

13. Kumar, R. and Lightner, R. (2007). "Games as an Interactive Classroom Technique: Perceptions of Trainers, College Instructors and Students.” International Journal of Teaching and Learning in Higher Education, 19(1): 53-63

14. Lammers, W. J., and Murphy, J. J. (2002). "A profile of teaching techniques used in the university classroom: A descriptive profile of a US public university". Active Learning in Higher Education, 3(1): 54-67.

15. Liu, R., Qiao, X., and Liu, Y. (2004). “A Paradigm Shift of Learner-Centered Teaching Style: Reality or Illusion?” Arizona Working Papers in SLAT, 13(2006): 77-91.

16. Maphosa, C., Zikhali, J., Chauraya, E. and Madzanire, D. (2013). "Students' Perceptions of the Utility of Pedagogical Approaches Used by Lecturers in Selected Faculties at a Zimbabwean University. "Journal Social Science, 6 (2): 113 122.

17. Ryan, M. P., and Martens, G.G. (1989).Planning a College Course: A Guidebook for the Graduate Teaching Assistant. Ann Arbor, Mich.: National Center for Research to Improve Postsecondary Teaching and Learning. Sajjad, S. (n.d).Effective Teaching Methods at Higher Education Level. Karachi: University of Karachi

18. Sakala, J. (2012). Factors contributing to excess use of the Lecture Method of teaching among High School Teachers in Selected Schools of Kitwe and Kalulushi Districts: Lessons for Educational Administrators. Unpublished Masters Dissertation Lusaka: University of Zambia. Shaari, A. S., Yusoff, N. M., Ghazari, I. M., Osman, R. H., and Dzahir, N. F. M. (2014). "The relationship between lecturers' teaching style and students' academic engagement." Procedia Social and Behavioral Sciences, 118(2014): 10-20.

19. Spoon, J.C., and Schell, J.W. (1998). "Aligning Student Learning Styles with Instructor Teaching Styles.” Journal of Industrial Teacher Education, 35(2): 41-56.

20. Westwood, P. (2008). What teachers need to know about teaching methods. Camberwell, Vic.: ACER Press. 